\title{
EPIDEMIOLOGY AND CLINICAL PRESENTATION OF NEONATAL FUNGAL SEPSIS IN INTENSIVE CARE UNITS OF PEDIATRIC CLINIC TUZLA
}

\author{
Devleta Hadžić, Evlijana Zulić, Dženana Ostrvica, Amela Selimović, Meliha Ćurčić
}

(C) 2019 by Acta Medica Saliniana ISSN 0350-364X

DOI: $10.5457 / 516$

Devleta Hadžić

Evlijana Zulić

Dženana Ostrvica

Amela Selimović

Meliha Ćurčić

\begin{abstract}
Introduction: Standing advances in neonatology increased survival of premature infants with the use of invasive procedures, which increases risk of infection and fungal sepsis. Risk factors for fungal sepsis are extensively studied. Candida is dominant, but there is increase in resistant $C$. non-albicans species. Mortality is high and requires timely suspicion of fungal sepsis, and adequate treatment to counteract the fatal outcome.
\end{abstract}

Objectives: to analyze the clinical and laboratory characteristics of neonates, treated in the neonatal intensive care unit because of microbiologically proven fungal sepsis.

Subjects and Methods: The restrospective observational study included 48 consecutive neonates, treated in Iintensive care unit of Pediatric Clinic Tuzla during three-year period (2016-2018), those with proven fungal sepsis, confirmed by positive blood culture. We analyzed perinatal history, clinical and laboratory presentation of disease, length of treatment and outcome. Statistical analysis applied standard methods, and the research was approved by the Ethics Committee of the institution.

Results: Of the total treated 921 neonates, confirmed fungal sepsis were found in 48 infants $(5.2 \%)$, evenly distributed by gender. Of perinatal risk factors, confirmed the prematurity and low birth weight, and significant were the presence of umbilical venous catheter, parenteral nutrition, longer antibiotic therapy and mechanical ventilation. Clinically, fungal sepsis manifested as late sepsis with respiratory higher requirements, lethargy, feeding difficulties and abdominal distension. The most common laboratory abnormalities were increased CRP, leukocytosis and thrombocytopenia. Outcome: 44 neonates (91.7\%) survived, while 4 neonates (8.3\%) died. Antifungal therapy lasted 20.6 \pm 6 days, and intensive treatment $38.2 \pm \mathbf{2 3 . 2}$ days. All isolates were Candida species, in vitro without resistance. In 8 neonates $(16.7 \%)$ recorded a slight toxic hepatitis.

Conclusion: Recovery of neonates with fungal sepsis depend on timely clinical suspicion, adequate treatment and monitoring. Antifungal susceptibility is also important, which requires monitoring of local epidemiological data to improve treatment.

Key words: fungal sepsis, neonates, epidemiology, clinical presentation, risk factors

\section{INTRODUCTION}

Although fungal sepsis (FS) in Neonatal Intensive Care Unit (NICU) is less common than sepsis caused by Gram- positive and Gram- negative bacteria, it has a higher morbidity and mortality rate, especially in preterm infants with low birth weight, while infants who survive often have long-term neurological damage [1]. The mortality rate is different and ranges from $20-75 \%$ [2]. The risk factors for neonatal FS have been extensively studied and include prematurity, low birth weight, indwelling central venous chateter use, prolonged hospitalization, mechanical ventilation, endotracheal intubation, parenteral nutrition, prolonged broadspectrum antibiotic use, exposure to $\mathrm{H}_{2}$ receptor antagonist, as well as previous Candida albicans colonization from mother [1-3].

Clinical presentations of FS have also been investigated as they are nonspecific in infants, and most commonly include thrombocytopenia, lethargy, glucose instability, increased requirements for ventilation or apnea [4]. It is very important for clinicians to be aware of constant risk of neonatal FS. Given the full extent of the problem, FS in critically ill infants should be considered with negative hemocultures, as early diagnosis and aggressive treatment improve overall 
outcome [5-6]. The definite diagnosis of FS is not always easy to confirm because isolation and identification of the pathogen takes time, which makes it reasonable for infants with suspected FS to be treated empirically with antifungal therapy while awaiting for the results of micobiological findings. Empirical antifungal therapy is based on local epidemiology monitoring of dominant agents in a particular unit [7-9].

Candida strains are most commonly reported as a causative agents of neonatal FS, but instead of the previously dominant (up to $80 \%$ ) sensitive Candida albicans, $a$ gradual increase in non- albicans Candida strainsincluding C.parapsilosis, C.tropicalisiC.glabrata that show varying degrees of resistance to fluconazole and other antifungal agents have been reported [5-9]. Therefore, the recommended prophylactic administration of Fluconazole is questionable, and its routine, empirical administration as the first- line therapy may be inappropriate [2]. It is very important to have current information on neonatal fungal isolates and their patterns of antimicrobial susceptibility, and thus be guided in the choice of empirical antifungal therapy [10-14].

Theaim of this study was to determine theepidemiology of FS in Intensive Care Union of the Clinic for Children's Diseases, University Clinical Center Tuzla over a threeyear period, and to anlayze the clinical presentation and presence of the most common risk factors in infants with microbiologically confirmed FS. For comparative purposes, a systematic review of published studies on the epidemiology of FS in critically ill infants was used.

\section{PATIENTS AND METHODS}

A retrospective observational study included all consecutive infants with hemoculture confirmed FS from the total number of treated patients in Intensive Care Union (ICU) of the Clinic for Children's Diseases (capacity 20 beds, level III) in the period from 1 January 2016 to 31 December 2018. All infants who had at least one positive fungi hemoculture or signs and symptoms of infections were taken into consideration in this study. Only the first episode of FS had been reported for patients with recurrent positive findings. The study also included infants undergoing treatment and those who crossed the first 28 days following birth, so that all infants with hemoculture isolated fungi were included in this study.

Clinical and demographic data were obtained from medical records and electronic database of patients treated in ICU, which included gender, gestational age, birt weight and predisposing risk factor for FS (presence of central venous catheter, length of mechanical ventilation, antibiotic therapy, parenteral nutrition and length of hospitalization). During admission, clinical status of infants was scored by SNAP (Score for Neonatal Acute Physiology), SNAP-PE (Score for Neonatal Acute Physiology - Perinatal Extension) i CRIB(Clinical Risk Index for Babies) [15].
Thestudywas approved by Hospital's Ethics Committee. The long- term antibiotics use was considered if it exceeded 14 days of a continuos administration. Late neonatal sepsis is defined as an infection that develops after the first 7 days of life. Fluconazole was used as the first line of empirical antifungal therapy. There was no prophylactic administration of Fluconazole in neonatal unit at the time of the trial, and empiric antibiotic therapy for neonatal sepsis was Ceftazidime, Amikacin, which was corrected by Meropenem and/or Vancomycin, depending on further clinical course and findings in the particular patient.

For comparative purposes, a systematic review of published studies on the epidemiology of FS in critically ill patients was used. Standard methods of descriptive statistics (central tendency measures, dispersion measures) were used. Parametric and nonparametric significance tests ( $\mathrm{X}^{2}$-test, Student's t- test) as well as linear correlation method were used to test the significance of differences between the samples. Statistical hypotheses were tested at a significance level of $\alpha=0.05$, i.e. the difference between the samples is considered significant if $\mathrm{P}<0.05$. We used Systat Software, Systat Inc, Evanstan, IL, USA for statistical processing of data.

\section{RESULTS}

During the three- year period, 921 infants were treated in ICU, and their basic clinical and demographic characteristics are shown in Table 1. Of total 921 treated infants, FS was found in 48 infants (5.2\%), evenly found in both genders. The basic clinical and demographic data of infants treated for FS are shown in Table 2. Mostly, it was about preterm infants with low birth weight with an average gestational age of $32.3 \pm 3.7$ and birth weight of $1852 \pm 746$ grams.

Table 1. Neonatal intensive care unit admitted patients characteristics $(n=921)$

\begin{tabular}{|l|l|l|l|l|}
\hline Characteristics & & & n & \% \\
\hline Neonates & & & $\mathbf{9 2 1}$ & $\mathbf{1 0 0 . 0}$ \\
\hline Preterm $(<37 \mathrm{GW})$ & & & 501 & 54.4 \\
\hline late preterm $(34-36 \mathrm{GW})$ & & 328 & 35.6 \\
\hline very preterm $(<32 \mathrm{GW})$ & & 173 & 18.7 \\
\hline extremely preterm $(<28 \mathrm{GW})$ & & & 58 & 6.2 \\
\hline low birth weight $(<2500 \mathrm{~g})$ & & & 278 & 30.1 \\
\hline very low birth weight $(<1500 \mathrm{~g})$ & & & 116 & 12.5 \\
\hline $\begin{array}{l}\text { extremely low birth weight } \\
(<1000 \text { g) }\end{array}$ & & 38 & 4.1 \\
\hline $\begin{array}{l}\text { Mechanical ventilation within } \\
\text { NICU stay }\end{array}$ & & & 330 & 35.8 \\
\hline Surgery within NICU stay & & & 46 & 4.9 \\
\hline Clinically confirmed sepsis & & 396 & 42,9 \\
\hline $\begin{array}{l}\text { Confirmed sepsis on blood } \\
\text { cultures }\end{array}$ & & & 235 & 25.5 \\
\hline $\begin{array}{l}\text { Confirmed fungal sepsis on } \\
\text { blood cultures }\end{array}$ & & 48 & 5.2 \\
\hline
\end{tabular}

GW - gestational weeks 
Table 2. Baseline characteristics of neonates with fungal sepsis

\begin{tabular}{|l|l|l|l|l|}
\hline Parametar & Mean & Minimun & Maximum & SD \\
\hline Gestational age (weeks) & 32.35417 & 25.00000 & 40.00000 & 3.789625 \\
\hline Birth weight (grams) & 1852.083 & 680.0000 & 3770.000 & 746.2700 \\
\hline AS $^{\text {st }}$ minute & 5.904762 & 2.000000 & 9.000000 & 2.119074 \\
\hline AS $^{\text {th }}$ minute & 6.952381 & 4.000000 & 9.000000 & 1.321975 \\
\hline PRM (hours) & 4.095238 & 1.000000 & 15.00000 & 4.134063 \\
\hline Postnatal age of admission to NICU (hours) & 3.142857 & 1.000000 & 24.00000 & 5.552348 \\
\hline Duration of mechanical ventilation (days) & 8.083333 & 0.00 & 41.00000 & 10.08018 \\
\hline Duration of NICU stay (days) & 32.12500 & 5.000000 & 100.0000 & 18.26708 \\
\hline CRIB II skor & 5.952381 & 1.000000 & 17.00000 & 4.318289 \\
\hline SNAPE-PE II skor & 36.80952 & 2.000000 & 74.00000 & 20.07889 \\
\hline
\end{tabular}

SD-standard devition; AS $1^{\text {st }}$ min-Apgar score in the first minute; AS $5^{\text {th }}$ minute-Apgar score in the fifth minute; PRM- premature rupture of membranes; NICU - neonatal intensive care unit; CRIB II- Clinical Risk Index for Babies scoring system; SNAPEPE II- Score for Neonatal Acute Physiology-Perinatal Extension

Prematurity and low birth weight in our study were confirmed as the most significant perinatal risk factors for the development of fungal sepsis in critically ill infants Table 3. Little significance in our stady had a vaginal birth.

Table 3. Perinatal risk factors in neonates with proven fungal sepsis

\begin{tabular}{|l|l|l|l|}
\hline Parameter & $\mathrm{n}$ & $\%$ & $\mathrm{p}$ \\
\hline Male & 25 & 52.1 & \\
\hline Female & 23 & 47.9 & \\
\hline Cesarean delivery & 18 & 37.5 & 0.01 \\
\hline Vaginal delivery & 30 & 62.5 & 0.009 \\
\hline Preterm infants $(<37 \mathrm{GW})$ & 42 & 87.5 & \\
\hline Late Prematurity $(34-36 \mathrm{GW})$ & 11 & 22.9 & \\
\hline Extreme prematurity $(<32 \mathrm{GW})$ & 31 & 64.6 & 0.009 \\
\hline Extreme Prematurity $(<28 \mathrm{GW})$ & 8 & 16.7 & \\
\hline Low birth weight $(<25009)$ & 39 & 81.25 & \\
\hline Very low birth weight $(<1500 g)$ & 20 & 41.7 & \\
\hline Extremely low birth weight $(<1000 g)$ & 4 & 8.3 & \\
\hline AS ${ }^{\text {st }}$ minute $<6$ & 9 & 18.7 & \\
\hline AS $5^{\text {th }}$ minute $<6$ & 6 & 12.5 & \\
\hline Maternal infections & 10 & 20.8 & \\
\hline PRM $>$ 12sati & 4 & 8.3 & \\
\hline
\end{tabular}

GW- gestational weeks; AS $1^{\text {st }}$ min- Apgar score in the first minute; AS $5^{\text {th }}$ minute-Apgar score in the fifth minute; PRM- premature rupture of membranes

The severity of illness in treated infants on admission was scored by neonatal tests (CRIB II and SNAPE-PE II), while the severe clinical picture of treated infants was confirmed by administered supportive therapy that was shown in Table 4.

Table 4. Severity of disease and interventions as risk factors for neonatal fungal sepsis

\begin{tabular}{|l|l|l|l|}
\hline Parameter & $\mathrm{n}$ & $\%$ & $\mathrm{p}$ \\
\hline Umbilical venous catheter & 48 & 100 & $>0.0001$ \\
\hline Broad spectrum antibiotics> 14 days & 10 & 20.8 & \\
\hline Mechanical ventilation & 43 & 89.6 & $>0.0001$ \\
\hline Parenteral nutrition & 48 & 100 & $>0.0001$ \\
\hline Inotropes & 15 & 31.5 & \\
\hline H2 receptor blockers & 12 & 25 & \\
\hline Irobiotics & 12 & 25 & \\
\hline Intravenous gammaglobulins & 14 & 29.2 & \\
\hline Ursodeoxycholic acid & 8 & 16.7 & \\
\hline Survived & 44 & 91.7 & \\
\hline Died & 4 & 8.3 & \\
\hline
\end{tabular}


All infants with fungal sepsis had an umbilical vein catheter, received parenteral nutrition and antibiotic therapy, and one fifth of them received prolonged a broad- spectrum antibiotic therapy. Almost 90\% of them required mechanical ventilation support, and the meanventilation support length was 8 days. Four infants underwent surgery for pneumothorax treatment. Of the other known risk factors for the development of FS, a quarter of our patients received $\mathrm{H}_{2}$ - receptor blockers and had prolonged hospitalization. Clinically, fungal sepsis manifested as a late sepsis in all 48 patients, and the most common clinical presentation included respiratory deterioration, lethargy, feeding difficulties, and abdominal distension. (Table 5).

Table 5. Clinical presentation of neonatal fungal sepsis

\begin{tabular}{|l|l|l|l|}
\hline Parameter & $\mathrm{n}$ & $\%$ & $\mathrm{p}$ \\
\hline Late onset sepsis (> 7 days of age) & 48 & 100 & $>\mathbf{0 . 0 0 0 1}$ \\
\hline Increasing respiratory requirement & 25 & 52.1 & 0.85 \\
\hline Temperature instability & 5 & 10.4 & \\
\hline Poor perfusion & 9 & 18.7 & \\
\hline Lethargy & 22 & 45.8 & 0.65 \\
\hline Abdominal distension & 14 & 29.2 & \\
\hline Feeding difficulties & 15 & 31.2 & \\
\hline Convulsions & 2 & 4.2 & \\
\hline
\end{tabular}

Laboratory findings in neonates with fungal sepsis are shown in Table 6. The most common deviation in our patients was presented as an increase in C- reactive protein and leukocytes with thrombocytopenia. (Table 7 ).

Table 6. Laboratory findings in neonates with fungal sepsis

\begin{tabular}{|l|l|l|l|l|}
\hline Parameter & Mean & Minimun & Maxsimum & SD \\
\hline CRP (mg/L) & 49.54792 & 1.000000 & 294.0000 & 70.13882 \\
\hline Hematocrit & 0.506190 & 0.370000 & 0.740000 & 0.093353 \\
\hline Leukocytes & 9.190476 & 3.400000 & 18.00000 & 3.756182 \\
\hline Neutrophils & 0.320952 & 0.110000 & 0.630000 & 0.148017 \\
\hline Absolute neutrophil count & 3250,000 & 920,0000 & 8800,000 & 2240,187 \\
\hline Platelets & 110.6667 & 3.000000 & 510.0000 & 97.57361 \\
\hline Albumins (g/L) & 26.42857 & 20.00000 & 41.00000 & 4.632186 \\
\hline Glucose (mmol/L) & 5.447826 & 0.1 & 23.3 & 4.088106 \\
\hline
\end{tabular}

SD-standard deviation; CRP- $C$ reactive protein

Table 7. Laboratory abnormalities in neonates with fungal sepsis

\begin{tabular}{|l|l|l|l|}
\hline Parameter & $\mathrm{n}$ & $\%$ & $\mathrm{p}$ \\
\hline CRP $<5 \mathrm{mg} / \ell$ & 15 & 31.3 & \\
\hline CRP $>5 \mathrm{mg} / \ell$ & 33 & 68.8 & 0.09 \\
\hline Htc anemia & 19 & 39.6 & \\
\hline Htc normal & 21 & 43.8 & \\
\hline Htc polycytemia & 8 & 16.7 & \\
\hline Leukocytes $<6 \times 10^{9} / \mathrm{L}$ & 17 & 35.4 & \\
\hline Leukocytes $>13 \times 10^{9} / \mathrm{L}$ & 31 & 64.6 & 0.09 \\
\hline ANC $<1800$ & 10 & 20.8 & \\
\hline ANC $>13000$ & 4 & 8.3 & \\
\hline thrombocytopenia $<150 \times 10^{9} / \mathrm{L}$ & 38 & 79.2 & 0.09 \\
\hline thrombocytosis $>450 \times 10^{9} / \mathrm{L}$ & 1 & 2.1 & \\
\hline Coagulation status normal & 25 & 52.1 & \\
\hline Coagulation status disturbed & 23 & 47.9 & \\
\hline Hypoglycemia & 15 & 31.3 & \\
\hline
\end{tabular}

CRP- C reactive protein; Htc- hematocrit; ANC- Absolute neutrophil count 
Fluconazole prophylaxis was not included at the time of the study, but Fluconazole therapy was included when there was a clinical suspicion of fungal sepsis and before the hemoculture findings were received. All hemoculture isolates were from the candida strains group without in- vitro resistance. The duration of Fluconazole therapy averaged $20.6 \pm 6$ days; 11 of them received supportive platelet concentrate; 14 patients received intravenous gamaglobulin. Despite its in vitro sensitivity, Fluconazole was not effective in the treatment of two infants and it was replaced by Amphotericin B.

The outcome for 44 infants (91.7\%) was favorable, while 4 infants $(8.3 \%)$ died. The lenght of intensive care was $38.2 \pm 23.2$ days. The difference between infants survivors and deceased was found in the Apgar score result, that was more often statistically significant lower than 5 in deceased infants. Also, statistical significance was found in the length of intensive care that was significantly longer in survived infants. In 8 infants (16.7\%) mild toxic hepatitis was recorded as a complication of the total treatment with transient enlargement of the liver, an increase in direct bilirubin and liver enzymes, which was successfully treated with supportive therapy and an oral ursodeoxycholic acid formulation.

\section{DISCUSSION}

Fungal sepsis (mainly Candida spp.) is an important cause of morbidity and mortality in critically ill infants [1-5].Our study has shown that candidemia is a common probem in critically ill infants, with an overall incidence of $5.2 \%$. This data is higher than those in the literatures of European countries reporting an incidence of 1.1-1.3\% infants who were treated in intensive care union [3-9], and North and South America reporting an incidence of $0.5^{-1.6 \%}[10,11]$, but it is lower than published data in Asia reporting an incidence of $4-7.7 \%$ [12-14]. This variability may reflect differences in neonatal clinical practice among countries, as well as in the design of the study and patients involved in it. In our study, infants with fungal sepsis were evenly arranged by gender, which was generally in concord with the published literature, or it was reported a slight advantage of male infants [1-3].

In nearly $90 \%$ of cases, it was about a preterm infants, while over $80 \%$ cases were with low birth weights, which was the most common result in published studies where dominated very immature infants $(\leq 32$ gestation weeks) and very low birth weight $(\leq 1500 \mathrm{~g})[1,3,5]$. It is known that the risk for fungal sepsis in infants is high due to aggressive and invasive treatment, such as central venous catheters, mechanical ventilation, parenteral nutrition and prolonged hopitalization [16]. In our study all patients had an umbilical vein catheter, received parenteral nutrition and antibiotic therapy, and one-fifth of them received broad- spectrum antibiotic therapy. Almost $90 \%$ of them required mechanical ventilation, and the mean mechanical ventilation support length was 8 days. Intravenous catheters are risk factors for Candida sepsis in critically ill infants because Candida spp. can adhere to platelets and fibrinogen on the surface, form biofilms that can be a source for systemic infection [16]. Central venous catheters and parenteral nutrition are reported to be major risk for infection with non-albicans Candida strains, both of which predispose to the formation of catheter biofilms. Amino acids from parenteral nutrition mediate cell differentation, that could explain the high incidence of Candida in neonates with a central venous catheter receiving amino acid-rich parenteral diet [16].

Most of our patients (89.6\%) were on mechanical ventilation support. Mechanical ventilation has been described as a risk factor for neonatal fungal sepsis, although there are also very rare reports describing non- invasive support with cotinuous positive airway pressure as a risk factor [2]. Four infants in our study underwent surgery for pneumothorax treatment. Other studies report a significantly higher proportion of surgical intervention in infants with fungal sepsis up to $44 \%$ [2], including necrotizing enterocolitis up to $25 \%$. Candida sepsis has been described as an uncommon cause of intenstinal perforation and necrotizing enterocolitis [2], and abdominal surgery has been reported as a risk factor for the onset of Candida sepsis regardless of birth weight [2].

Fungal sepsis manifested as late neonatal sepsis in all patients, which is the most common result in other studies, and only rarely Canida is reported as the cause of early neonatal sepsis [17]. Clinical presentation in our study included respiratory deterioration, lethargy, feeding difficulties and distension of the abdomen, which is also consistent with reports from other studies [13]. The most common laboratory results deviation in our patients were an increase in C- reactive protein, leukocytes and thrombocytopenia [13]. All hemoculture isolates in our study were from Candida spp. group without in vitro resistance, which is consistent with some published studies $[1-3]$. There are regional differences in the incidence of the most common Candida strains. Through a systematic literature review, we found out that four Candida species (C. albicans, C. parapsilosis complex, C. tropicalis i C. glabrata complex) are associated with more than $95 \%$ cases of neonatal candidemia, but the distribution of these four species is different. In general, Candida albicans was the dominant isolated strain in Europe [3-9] and North and South America [10-11], and non- albicans strains were dominant in Asia [12-14]. However, more recent studies report constant growth of Candida non-albicans strains, with a frequency higher than $50 \%$ in some neonatal intensive care unions. This is partly associated with an increase in clinical use of the azole antifungal therapy and prophylaxis [18-20], although this has also been reported in hospitals where Fluconazole has rarely been used for prophylaxis and therapy [3]. Even some earlier reports, such as the Helsinki report 
[21] mention the emergence of Fluconazole resistance in a $C$. parapsilosis strain after more than 10 years of Fluconazole prophylaxis in neonatal intensive care unions. There was a high incidence of Fluconazole resistance in $C$. parapsilosis in this study, so that routine use of Fluconazole prophylaxis in this constellation is questionable. The outcome for infants (91.7\%) in this study was favorable, while 4 infants $(8.3 \%)$ died. Mortality rate due to neonatal fungal sepsis varied, and it is mostly high. It goes from $40 \%[2,-]$ up to $75 \%$ [22], and is considered low if it is below 20\% [23].The difference between survivors and deceased in our study was found only for the Apgar score and the length of intensive care. Mortality in other studies are mainly related to known risk factors and their correlation.

\section{CONCLUSION}

Candida sepsis is an important cause of morbidity and mortality in critically ill infants. The incidence at our hospital is 5.2 per 100 admissions to Neonatal Intensive Care Union. Perinatal risk factors for fungal sepsis are prematurity and low birth weight. The umbilical vein catheter, parenteral nutrition, antibiotic therapy and mechanical ventilation are also considered to be significant risk factors.

\section{SAŽETAK}

Uvod: Stalni napredak u neonatologiji povećava preživljavanje nedonoščadi uz primjenu višestrukih invazivnih procedura, što neminovno povećava rizik infekcije, a time i gljivične sepse. Faktori rizika za gljivičnu sepsu opsežno su proučavani. Candida je dominantan uzročnik, ali se bilježi porast rezistentnih ne-albicans vrsta. Mortalitet je visok i nalaže pravovremeno postavljanje kliničke sumnje na gljivičnu sepsu i adekvatan tretman da se preduprijedi loš ishod. Cilj: Cilj rada bio je da se analiziraju kliničke i laboratorijske karakteristike novorođenčadi liječene $\mathrm{u}$ intenzivnoj jedinici zbog mikrobiološki dokazane gljivične sepse.

Ispitanici i metode: Restrospektivnom opsrevacionom studijom obuhvaćeno je 48 konsekutivne novorođenčadi, liječene u Odjeljenju intenzivne terapije Klinike za dječije bolesti Tuzla u trogodišnjem periodu (2016-2018), a koja su imala dokazanu gljivičnu sepsu, potvrđenu pozitivnom hemokulturom. Analizirani su perinatalna anamneza, klinička i laboratorijska prezentacija bolesti, dužina liječenja i ishod. U statističkoj obradi korištene su standardne metode, a istraživanje je odobreno od strane Etičkog komiteta ustanove.

Rezultati: Od ukupno liječenih 921 novorođenčeta, gljivična sepsa potvrđena hemokulturom nađena je u 48 novorođenčadi $(5,2 \%)$, ravnomjerno raspoređenih po spolu. Od perinatalnih faktora rizika potvrđeni su prematuritet i niska porođajna težina, a značajni su bili umbilikalni venski kateter, parenteralna prehrana, antibiotska terapija i mehanička ventilacija. Klinički se gljivična sepsa manifestovala kao kasna sepsa sa respiratornim pogoršanjem, letargijom, teškoćama hranjenja i distenzijom trbuha. Najčešće laboratorijske abnormalnosti bile su porast CRP, leukocitoza i trombocitopenija. Ishod za 44 novorođenčadi $(91,7 \%)$ bio je povoljan, dok je 4 novorđenčadi $(8,3 \%)$ umrlo. Antifungalne terapije trajala je $20,6 \pm 6$ dana, a

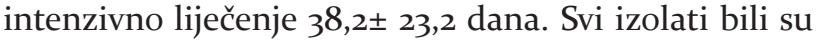
iz grupe Candida species bez in-vitro rezistencije. Kod 8 novorođenčadi $(16,7 \%)$ zabilježen je blagi toksični hepatitis.

Zaključak: Povoljan ishod novorođenčadi s gljivičnom sepsom zavisi od pravovremene kliničke sumnje, adekvatnog tretmana i nadzora. Antifungalna osjetljivost takođe je bitna za djelotvorno liječenje, stoga je važno pratiti lokalne epidemiološke podatke kako bi se olakšao izbor liječenja.

Ključne riječi: gljivična sepsa, novorođenče, epidemiologija, klinička prezentacija, faktori rizika

\section{REFERENCES}

1. Caggiano G, Lovero G, De Giglio O, Barbuti G, Montagna O, Laforgia N,Montagna MT. Candidemia in the Neonatal Intensive Care Unit: A Retrospective, Observational Survey and Analysis of Literature Data. Biomed Res Int 2017; 2017: 7901763.

2. Ballot DE, Bosman N, Nana T, Ramdin T, Cooper PA. Background changing patterns of neonatal fungal sepsis in a developing country. J Trop Pediatr 2013; 59(6): 460-464.

3. Celebi S, Hacimustafaoglu M, Koksal N, Ozkan H, Cetinkaya M, Ener B. Neonatal candidiasis: Results of an 8 year study. Pediat Internat 2012; 54(3): 341-349.

4. Testoni D, Hayashi M, Cohen-Wolkowiez M, et al. Late-onset bloodstream infections in hospitalized term infants. Pediatric Infectious Dis J 2014; 33(9): 920-923.

5. Kelly M S, Benjamin D K, Smith P B The epidemiology and diagnosis of invasive candidiasis among premature infants. Clinics in perinatology 2015; 42(1): 17-105.

6. Leibovitz E. Strategies for the prevention of neonatal candidiasis. Pediat Neonatol 2012; 53(2): 83-89.

7. Borghi E, Sciota $R$, Iatta $R$, Biassoni C, Montagna M T, Morace G. Characterization of Candida parapsilosis complex strains isolated from invasive fungal infections. Europ J Clin Microbiol Infect Dis 2011; 30(11): 1437-1441.

8. Tortorano A M, Prigitano A, Lazzarini C, et al. A 1-year prospective survey of candidemia in Italy and changing epidemiology over one decade. Infection 2013; 41(3): 655-662. doi:

9. Pfaller M, Neofytos D, Diekema D, et al. Epidemiology and outcomes of candidemia in 3648 patients: data from the Prospective Antifungal Therapy (PATH Alliance) registry, 
2004-2008. Diag Microbiol Infect Dis 2012; 74(4): 323-331.

10. Robinson J A, Pham H D, Bloom B T, Wittler RR. Risk factors for persistent candidemia infection in a neonatal intensive care unit and its effect on mortality and length of hospitalization. J Perinatol 2012; 2(8): 1-625.

11. Hoffmann-Santos H D, Paula C R, Yamamoto ACA, Tadano T, Hahn RC. Six-Year Trend Analysis of Nosocomial Candidemia and Risk factors in Two Intensive Care Hospitals in Mato Grosso, Midwest Region of Brazil. Mycopathologia 2013; 176(5-6): 409415.

12. Chen I, Chiu N, Chi H, et al. Changing of bloodstream infections in a medical center neonatal intensive care unit. J Microbiol Immunol Infection 2015 doi: 10.1016/j. jmii.2015.08.023.

13. Chaurasia D, Goel M, Dhruw S, Dubey D, Dwivedi R. Changing Pattern of Neonatal Fungal Sepsis: A Matched Case - Control Study. National J Med Allied Sci 2015;4(1) Online first.

14. Wadile R, Bhate V. Study of clinical spectrum and risk factors of neonatal candidemia. Indian J Pathol Microbiol 2015; 58(4): 472-474.

15. Dorling JS, Field DJ, Manktelow B. Neonatal disease severity scoring systems. Arch Dis Child Fetal Neonatal Ed 2005; 90(1): F11-F16.

16. Hammoud MS, Al-Taiar A, Fouad M, Raina A, Khan Z. Persistent candidemia in neonatal care units: Risk factors and clinical significance. Internat J Infect Dis 2013; 17(8): e624-e628.

17. Bizzarro MJ, Shabanova V, Baltimore RS, Dembry LM, Ehrenkranz RA, Gallagher PG. Neonatal sepsis 2004-2013: The rise and fall of coagulase-negative staphylococci. J Pediatrics 2015; 166(5): 1193-1199.

18. Juyal D, Sharma M, Pal S, Rathaur VK, Sharma N. Emergence of non-albicans Candida species in neonatal candidemia. North Amer J Med Sci 2013; 5(9): 541-545.

19. Khan EA, Choudhry S, Fatima M, Batool Z. Clinical spectrum, management and outcome of neonatal candidiasis. J Pakistan Med Assoc 2015; 65: 1206-1209.

20. Pappas PG, Kauffman CA, Andes DR, Clancy CJ, Marr KA, Ostrosky-Zeichner L, et al. Clinical practice guideline for the management of candidiasis: 2016 update by the infectious diseases society of America. Clin Infect Dis 2016; 62 :e1-50.

21. Sarvikivi E, Lyytikainen O, Soll DR, et al. Emergence of fluconazole resistance in a Candida parapsilosis strain that caused infections in a neonatal intensive care unit. J Clin Microbiol 2005; 43: 2729-2735.
22. Sardana V, Pandey A, Madan M, et al. Neonatal candidemia: a changing trend. Indian J Pathol Microbiol 2012; 55:132-133.

23. Rodriguez D, Almirante B, Park BJ, et al. Candidemia in neonatal intensive care units: Barcelona, Spain. Pediat Infect Dis J 2006; 25(3): 224-229.
Scan this QR code with your mobile device for instant access to the current Issue of Acta Medica Saliniana

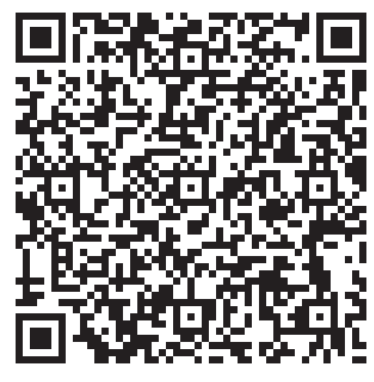

